$\mathbb{T}$ periodica polytechnica

Civil Engineering

$51 / 1(2007) 25,31$

doi: 10.3311/pp.ci.2007-1.04

web: http://www.pp.bme.hu/ci

(c) Periodica Polytechnica 2007

RESEARCH ARTICLE

\section{A special GIS application - military historical reconstruction}

Attila Juhász

Received 2006-04-03

\begin{abstract}
GIS is increasingly becoming popular in many humane disciplines such as archaeology, anthropology. In our research we use it to support military historical reconstruction. We deal with the Attila-line, which was a defence line around Budapest in the secnd World War. Up to now the researchers could find only short descriptions and sketches about this defence line. Our goal was a detailed and reliable reconstruction, which contains environmental, object, and event parts. To get through with this task we had to collect and manage a lot of variable-quality archive data. This information comes from different sources: libraries, archives, archive maps and aerial photographs, field measurements, and personal reminiscences. We can manage this information in a standard system with GIS. The investigation consists of three main parts: the reconstruction of the contemporary environment, the reconstruction of the defence objects, and the reconstruction of the military events. This database can be used as a reference system to support further research and to identify new parts of the defence line. Using the attributes we can make queries and various reviews. The database is usable as a digital data archive, too. Our next research goal is to follow the search of the Attila-line and other defence lines and to present them to wider scientific and public audiences.
\end{abstract}

\section{Keywords}

GIS $\cdot$ remote sensing $\cdot$ military history $\cdot$ object reconstruction $\cdot$ Attila-line

\section{Attila Juhász}

Department of Photogrammetry and Geoinformatics, BME, Múegyetem rkp. 3. Budapest, H-1521, Hungary

e-mail: atjuhasz@eik.bme.hu

\section{Defence Lines in World War II.}

The goal of the fortifications is to enlarge own forces' fight ability and to reduce the enemy's chances and possibilities. The fortification is the synchronic usage of hiding, reinforcing the environment and conforming to it. The endurance of these fortifications depends on the time for the creation, the materials, the tools, the manpower and the impact of the enemy forces. On these grounds, there are two major types of fortifications: the field-fortifications and the permanent-fortifications Schmoll 1930 [3].

Many defence lines were created between the two great wars based on the WW I experiences. Almost every European Power built fortifications near their hazardous borders. The best-known example is the French Maginot-line along the German border. In front of this on the German side there was the Siegfriedline. The Russian Stalin-line, the Finnish Mannerheim-line, the Greek Metaxas-line all were built in this period. The builders of these defence lines trusted in their powers very much but almost in every case they were disappointed. The new weapons in WW II meant a new challenge and in some cases the lines became negligible because of the border modifications.

The Hungarian planners and contractors of that time studied the foreign examples, and they applied the foreign experiences and considered new theoretical and practical aspects when the Hungarian defence system was created. Thanks to this new approach the Hungarian forces succeeded in defence proportionately. The Árpád-line in the East-Carpathian stopped the Russian attack and held it up until the pull-out. If we take into consideration the conditions (the time for creation, the manpower, and the difference between the offensive and defensive forces) we can say that the Attila-line which defended Budapest turned out to be a great success. The real function of the Hungarian fortifications was to defend the oil-fields in the Transdanubian region and to protect south-eastern borders of Germany (Fig. 1). The shape of such a fortification system caused that Budapest endured one of the biggest sieges in the WW II. 


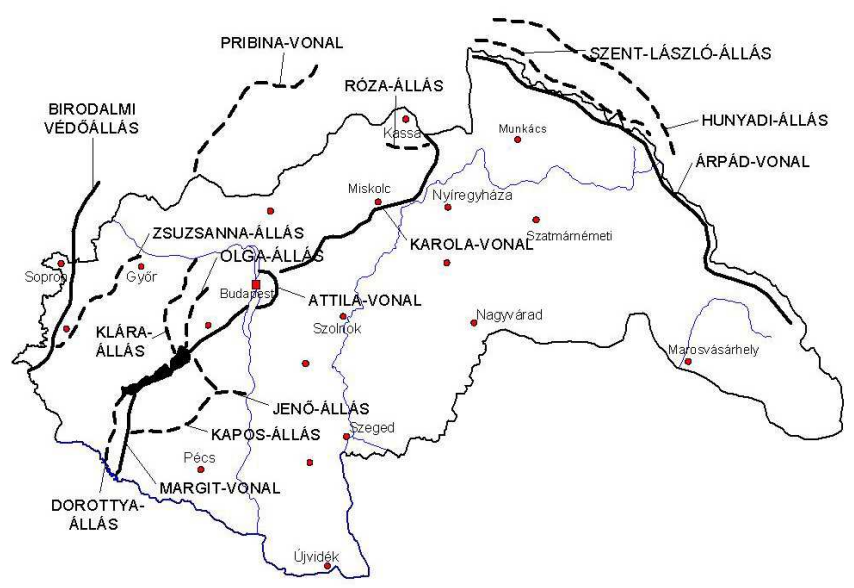

Fig. 1. Defence lines in Hungary (1944-45).

\section{The Attila-line}

In 1944 when the Russian forces reached the borders of Hungary the Hungarian High Military Command planned to stop the attack in the Carpathian. The plan was successful, but when Romania deserted to the Russian side the southern front collapsed. Only a few German divisions escaped from Romania. So the Soviet forces could get around the German-Hungarian defence, and attack through the South-Carpathian and towards the Hungarian Plain. In the new situation, the defence forces had to create a new fortification system across the whole country. The defence of the capital was a major consideration in this new system. So in September 1944, the German commander Hans Freissner ordered to build the Attila-line around Budapest. This horseshoe-shaped line contained three zones (Attila I., Attila II., Attila III. lines). The line was completed in November Ungváry 2001 [5]. In the course of the building, they created anti-tank dikes, rifle placements and trenches and field-artillery placements. The flaks which were built earlier also integrated into the system. The anti-tank dikes were the base of the defence lines. These 5-6 meters wide and 8-10 meters deep dikes have been dug by ten thousands of people. The dikes alone did not mean full defence. The Russian technical corps could easily get over these objects by erecting bridges over these dikes. So the defenders had to place rifle and artillery placements not so far behind the anti-tank dikes to arrest these Russian corps.

As we mentioned earlier the researchers of this theme could find only short descriptions and sketches about this defence line. Here is the best known description:

"The Attila-line was built from 22-nd of September 1944. With its wings lean on the river Danube and connected the Karola- and Margit-lines. The Attila-line had three defence zones (Attila I. II. III.). The outer one followed the Dunaharaszti - Vecsés - Ecser - Maglód - Valkó - Gödöllő - Szada Veresegyház - Csomád - Alsógöd line, the middle one followed the Soroksár - Soroksárpéteri - Pestszentimre - Pécel - Isaszeg - Kerepes - Mogyoród - Fót - Dunakeszi line, and the inner one was on the margin of the time suburbs of Csepel - Pest- szenterzsébet - Pestszentlőrinc - Rákoskeresztúr - Rákoscsaba - Cinkota - Rákosszentmihály - Rákospalota - Újpest. It did not run on the Buda side. The line was not built totally because of lack of manpower, soldiers, time, tools and weapons" Tóth 1975 [4].

In addition there are few imprecision sketches and map from the line but none of these is useable to carry out sound research work. The archive aerial photographs made by the fighting forces are difficult to get hold of.

\section{The Reconstruction Process}

The military historical reconstruction is a special process. We had to manage a lot of information with different precision and reliability. The archive data sources were the base of data collection. Beside GIS and remote sensing, the investigators had possessed experience and knowledge of many disciplines such as: history, geography, weapon knowledge, civil engineering, cartography, etc. To reach a precise and reliable result we have to manage this information and knowledge in a uniform system. The GIS is perfect for this task. In a GIS project we collect, manage and display spatial data. We can conclude that data of military historical reconstruction are principally spatial data.

We divided this study to three parts according to the reconstruction task. Each part relies on the previous one. The first step is the environmental reconstruction, then the second step is the object reconstruction and finally the last step is the event reconstruction. We had to create the GIS data system considering different viewpoints and demands. Researchers and ordinary enquirers are the potential users: hereinafter let us see the most important factors in creating a military historical GIS database:

- First we must mention the uniform data management. Our project's frame is the Carpathians, and the most suitable coordinate-system at our disposal is the Hungarian EOV coordinate-system.

- Beside the geometrical presentation of the reconstruction objects, we created an attribute-database which contains the environmental and military object's properties.

- In this kind of GIS application we represented many various documents that are not needed in conventional GIS applications (local-governing, public works). These documents can be texts, photos, videos, CAD files. On the other hand, there is another account to collect this type of documents. In this way we can create digital document archives.

- The obtained sample database can be used as a reference and registry system. Therefore it must contain the search period's typical fortification objects. In the last few years we studied a couple of foreign samples, to promote military object search and identification.

- The sample database constitutes a suitable base for further research. So carrying out careful research and implementing sound methods are very necessary steps. 


\subsection{The Environmental Reconstruction}

The first step in our project is the environmental reconstruction. At first glance we may think that this is an unnecessary step because of the most wanted goals are the military objects and the events. However, the presentation of the period environment is necessary in most of the cases, especially in military history. The geographical environment and the terrain always have an important role in strategy (Kozma, Héjja, Stefancsik 1993, [2]). Beside the strategical viewpoint there are more important reasons in reconstructing the environment. This component creates the frame of the objects and events. The user can easily get orientation, too. The attributes of the environmental objects (size, shape, form) can signal out that there was a fortification on the searched area, so we can use the vegetation as an indicator. Further on, in event reconstruction we also need to represent the environment, because in most of the cases there are only few data sources and the information is associated with the environment. In practice this part of the project means that we create a digital base map.

\subsection{The Military Object Reconstruction}

In this component we had to reconstruct the part of the searched defence line. This was the biggest and the most interesting component, because of the result obtained through complex search work. Unlike the environmental objects here we searched not only the geometrical data but the attributes, too. The common data sources also had the archive sources. Before the direct researching (interpretation of the archive aerial photos and maps) it was helpful to study the geometrical data and the attributes of the searched military objects. The most important questions we had to answer is what we search and where. Along the previous researching we collected a lot of publications about the Attila-line: books, archives, articles etc. We also studied the fortification regulations of the fighting armies (Fig. 3). In the German, Russian and Hungarian regulations we found exact information about the fortification objects. After having finished the previous data collection we began to know the size of the defence objects and the whole Attila-line, so we decided the scale of the data collection and the data density of the GIS project.

After the previously mentioned data collection the map and aerial photograph interpretation was carried out. Maps of scale $M=1: 25000$ and $M=1: 10000$ were used to locate the big objects like anti-tank dikes, flaks and areas which were attacked heavily with artillery fire. The large number of aerial photographs was the base for search and object location. We used aerial photographs that were taken in the 1950's. The photographs have larger information content than the maps. A skilful photointerpretator specialist can locate the trenches and rifle placements. In addition we can interpretate the covered anti-tank dikes from the photos, because along this covered dikes the field quality has changed (drainage, temperature, colour, nutriment content, vegetation). In this case we used vegetation as indicator. The final step of the object reconstruction, is the field data collection, this

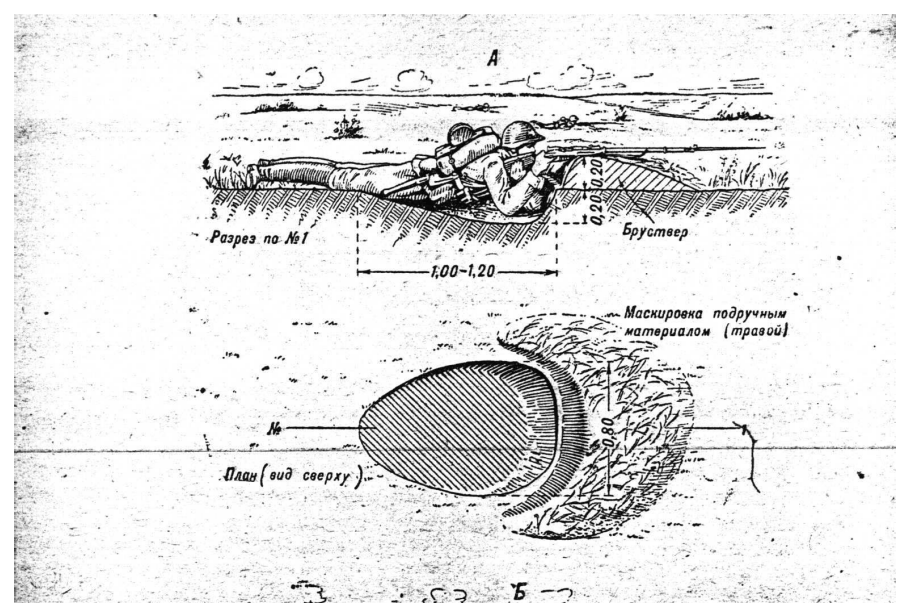

Fig. 2. Rifle dike according to the a Russain fortification regulation

included in-site field measurements and other ground-truth data collection.

\subsection{The Event Reconstruction}

After a successful environmental and fortification object reconstruction we can proceed to reconstruct the military events. While the object reconstruction is possible without environmental reconstruction, for presenting the events we always need the previous two steps. The event presentation accuracy depends on two factors. First, when the event happened and second what kind of data sources can be used. These two factors are naturally related. We can notice that when we move more and more back in time the amount and value of data available gets lower. There are some important considerations we meet during data collection and the presentation such as the personal reminiscences has an important role in this reconstruction part, but in most cases we can not verify such information which in many cases can reflect conflicting facts. The solution to this problem is to present all the alternatives or create a reliability scale. To represent the events in GIS we can use levels (as thematic maps) or link animations.

\section{Data Sources}

The data sources or data collection methods used for military historical reconstruction can be grouped in many different ways. In our research we used GIS for the sample reconstructions, so hereinafter we review the group method used in Geoinformatics. According to the first point of view, we can make out primarily geometrical and primarily attribute data collection methods. Both of these methods can be grouped further. In either case there are primary and secondary data sources. In the primary case we collect the information directly from the object or its image. In the secondary case, we use ready databases.

There are many differences between the primary and the secondary data collection methods in relation to data quality, expenses and data collection time. The primary data sources are more expensive and need more time and work. But accordingly 
their quality isbetter than the secondary data and we can take into consideration the current task's specialties, using the primary methods (Detrekői, Szabó, 2002) [1].

A military historical reconstruction is a special task from the point of view of data collection. The most important method is using archive data sources. In Hungary, the first aerial photograph that covered the whole country was taken in the 1950 s. These early photographs proved to be very useful in our research. We also applied archive maps to allocate the potential research areas. Along the reconstruction we had to collect such interesting data types like personal reminiscences and stories. Conventional GIS applications rarely need this kind of data source. Next we review the applied data collection methods and their main properties (Fig. 3).

\begin{tabular}{|c|c|c|c|}
\hline PREVIOUS & $\begin{array}{l}\text { ARCHIVE } \\
\text { MAPS. }\end{array}$ & $\begin{array}{l}\text { ARCHIVE } \\
\text { ARIAL }\end{array}$ & FIELD \\
\hline $\begin{array}{l}\text {-WRITTEN } \\
\text { DOCS } \\
\text {-VERBAL } \\
\text { INFOS }\end{array}$ & $\begin{array}{l}\text {-APPROXI- } \\
\text { MATE } \\
\text { LOCATION }\end{array}$ & $\begin{array}{l}\text {-PRECISE } \\
\text { INTERPRE- } \\
\text { TATION }\end{array}$ & $\begin{array}{l}\text {-CONTROL } \\
\text {-NEW } \\
\text { INFOS }\end{array}$ \\
\hline
\end{tabular}

Fig. 3. The steps of data collection

Previous data collection: At the start of this study we have to collect as many information about the selected fortification as we can. We have to define what we are looking for, where to look and how to find it. This information may come from two base data sources:

- written or drawn documents, like different present-day or the period publications, books, archives, maps, sketches

- verbal information like personal reminiscences, stories of the war veterans or eyewitnesses.

It is very important to find the reliable and independent publications and persons, because in most cases we meet conflicting information about the same thing. Many times it is difficult to find the truth.

Archive maps: Once we know the fortification size and area it is located in, it is recommended to review the archive maps created in the searched period. If the fortification size is big enough we may find relief signs or marks which may be related to the searched object. Our task will be easier if we find large scaled maps and maps that were created in the same time or near time of the fortification building.

Archive aerial photographs: The aerial photo interpretation is one of the most important parts along fortification reconstruction. The earliest Hungarian territory aerial photographs were made 5-6 years after the WW II. These black-and-white images are of poor quality. A few years later the colour and infrared images appeared. From the reconstruction viewpoint, the oldest images are the best because after the WW II the geographical environment changed significantly. The cultivated and built-in areas increased rapidly. Therefore the fortifications parts made of mixture of soil and wood decayed continually. Fortunately in case of large fortification parts (10-20 meters wide and 3-4 meters deep) there is a good chance to locate the berried dikes or objects. The objects under the surface change the ground's attributes such as temperature, water throughput, nutrient content. Because of these changes, it is not too difficult to interpret the images. The researcher has to monitor the regular or linear formations areas which have different colour or vegetation parameter than their environment.

Field data collection: In most cases the last step of the process is the field data collection. It is worthy to start this phase after the other data collection phases, otherwise our task will be difficult to achieve. If we know the searched object's major attributes, then we have a good chance to find it and get new information. The field data collection has two basic goals. At first we can verify the information coming from other data sources, second we can find new fortification objects or parts. Beside the above mentioned goals we can trace down the present-day status of such objects. Regarding the measurements we can conclude that the quality required is about 1-2 meters generally. To realize this quality we can apply traditional geodesic methods or use simple GPS navigation receiver. It is enough to measure the main points of the located object and after a coordinate transformation we can fit it to our uniform system.

Tab. 1. Archive aerial photos from the Attila-line region

\begin{tabular}{llll}
\hline Section & Scale & $\begin{array}{l}\text { Useful } \\
\text { piece }\end{array}$ & Typical settlements \\
\hline L-34-3-C-d & $1: 20000$ & 12 & Alsógöd \\
L-34-15-A-b & $1: 20000$ & 9 & Dunakeszi, Fót \\
L-34-15-A-d & $1: 20000$ & 7 & K.megyer, Rákosszentmihály \\
L-34-15-B-a & $1: 20000$ & 7 & Gödöllö, Szada \\
L-34-15-B-b & $1: 20000$ & 8 & Bag, Aszód \\
L-34-15-B-c & $1: 20000$ & 7 & Kistarcsa, Csömör \\
I-34-15-B-d & $1: 20000$ & 7 & Valkó, Isaszeg \\
L-34-15-C-b & $1: 20000$ & 7 & Pestszenterzsébet \\
L-34-15-C-c & $1: 10000$ & 3 & Dunaharaszti \\
& $1: 6000$ & & \\
L-34-15-C-d & $1: 20000$ & 7 & Soroksár \\
L-34-15-D-a & $1: 20000$ & 7 & Gyömrő \\
L-34-15-D-b & $1: 20000$ & 7 & Maglód, Pécel \\
L-34-15-D-c & $1: 20000$ & 7 & Vecsés, Üllő \\
L-34-27-A-a & $1: 10000$ & 4 & Taksony \\
L-34-27-A-b & $1: 20000$ & 4 & Ócsa \\
\hline
\end{tabular}

\section{Data Collection for the Attila-line Reconstruction}

We selected the Attila-line in our research as a simple fortification to reconstruct. It protected Budapest in WW II. It lied on the Pest side of the Danube started from Dunakeszi, Alsógöd area on the north and finished at the territory of Dunaharaszti and Soroksár on the south. The data collection method we applied follows the principles mentioned above. At first we studied previous publications and documents about the defense line. 
Tab. 3. The military object reconstruction features

\begin{tabular}{|c|c|c|c|c|}
\hline $\begin{array}{l}\text { Feature } \\
\text { Class }\end{array}$ & Feature & $\begin{array}{l}\text { Geometrical } \\
\text { representation }\end{array}$ & TypicalAttributes & $\begin{array}{l}\text { Presentation } \\
\text { Scale }\end{array}$ \\
\hline \multirow{4}{*}{$\begin{array}{l}\text { Field } \\
\text { fortification } \\
\text { objects }\end{array}$} & Defence line & Line & Name, Build date & from $M=1: 300000$ \\
\hline & Anti-tank dike & Line & $\begin{array}{l}\text { Wide, Deep, B.date, Fight. forces, } \\
\text { period, Reliability }\end{array}$ & \multirow[t]{4}{*}{ to $M=1: 300000$} \\
\hline & Trench & Area & $\begin{array}{l}\text { Wide, Deep, B.date, Fight. forces, } \\
\text { period, Reliability }\end{array}$ & \\
\hline & Placement & Area & Type, Wide, Deep, Reliability & \\
\hline \multirow[t]{5}{*}{ Other objects } & Other military object & Area & Type, Name, Address, Reliability & \\
\hline & Link icon & Area & - & to $M=1: 10000$ \\
\hline & GPS point & Point & - & \multirow[t]{3}{*}{ to $M=1: 300000$} \\
\hline & Wrack & Point & Type, Name, Address, Reliability & \\
\hline & Other & Area & Type & \\
\hline
\end{tabular}

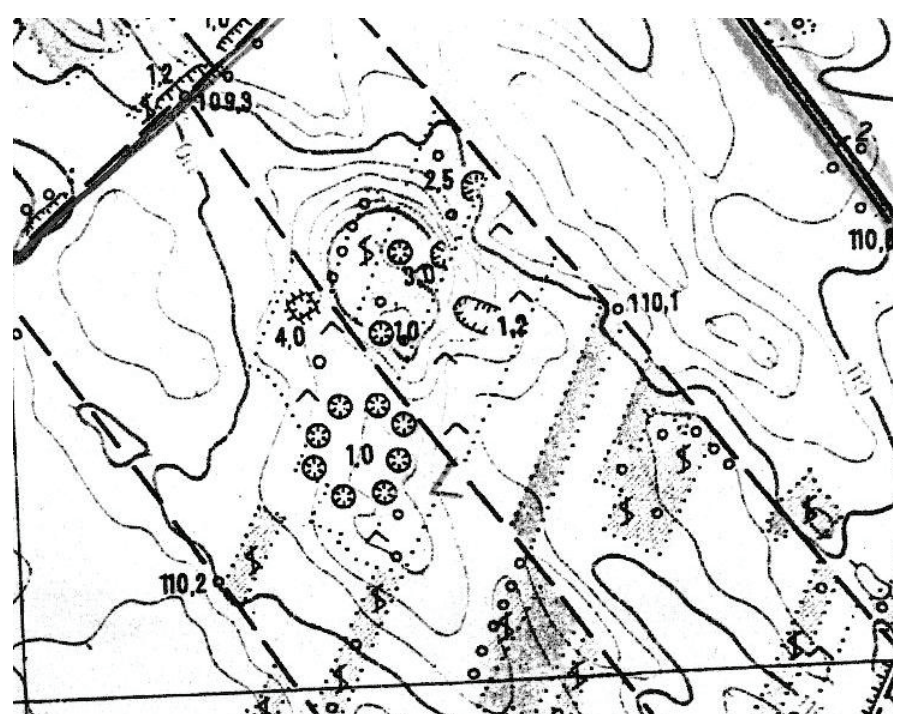

Fig. 4. Flak placement on a map

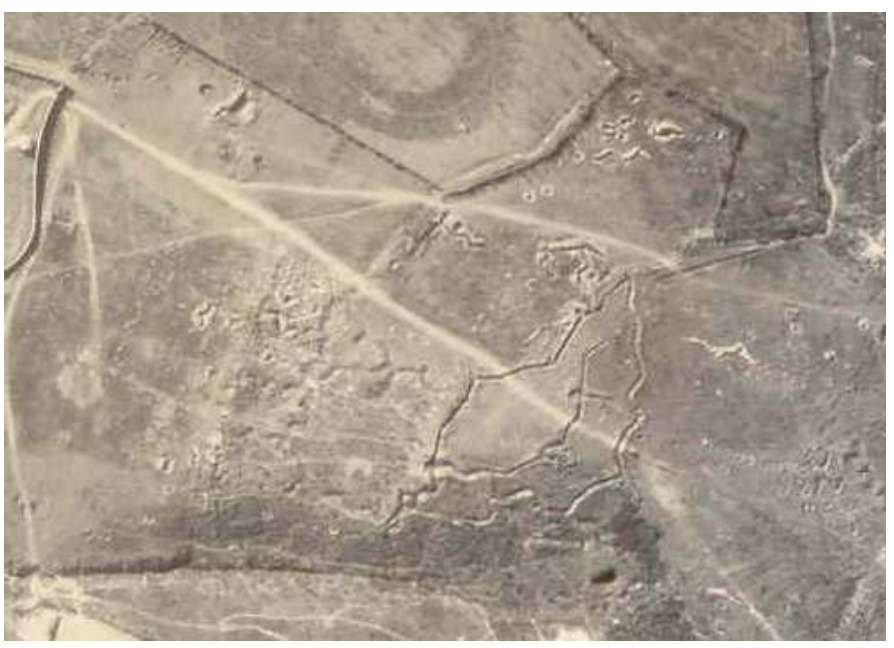

Fig. 5. Rifle placement near Sashegy



Fig. 6. Anti-tank dike part near Alsónémedi



Fig. 7. Data sources used in the reconstruction of Attila-line and their reliability 


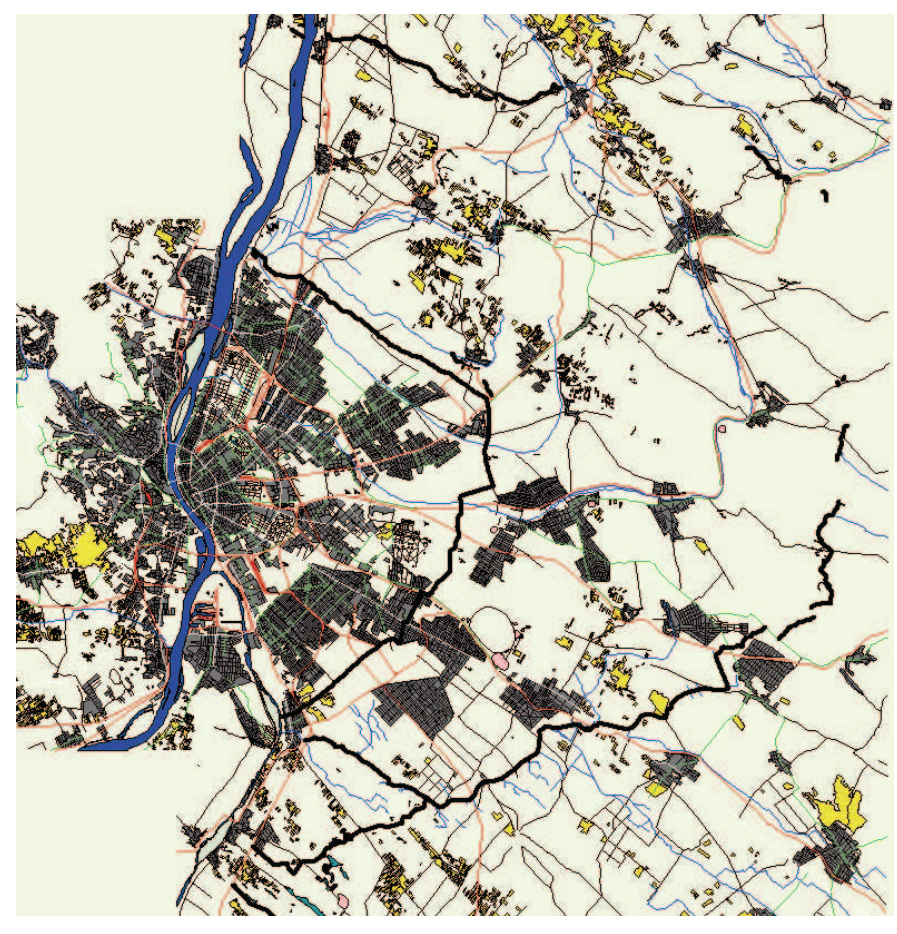

Fig. 8. The reconstructed Attila-line



Fig. 9. Flacks near Soroksár

Soon, it was clear that there existed only a short and general description about it, maps, plans were missing. After the previous search, the maps processing followed. We looked over the $\mathrm{M}=1: 25000$ and $\mathrm{M}=1: 10000$ scaled archive maps but this data source did not bring very new information, too. Following the descriptions we found signs in some areas which refer to antitank dikes and military placements precisely. The number of these signs was not significant. The real breakthrough was the archive aerial photo interpretation. This part provided the majority of the results. We interpretated hundreds of photos from the area, there were about one hundred useful images.

The anti-tank dikes can be located relatively easy on the photographs. Some of these dikes were still uncovered in the 1950s.

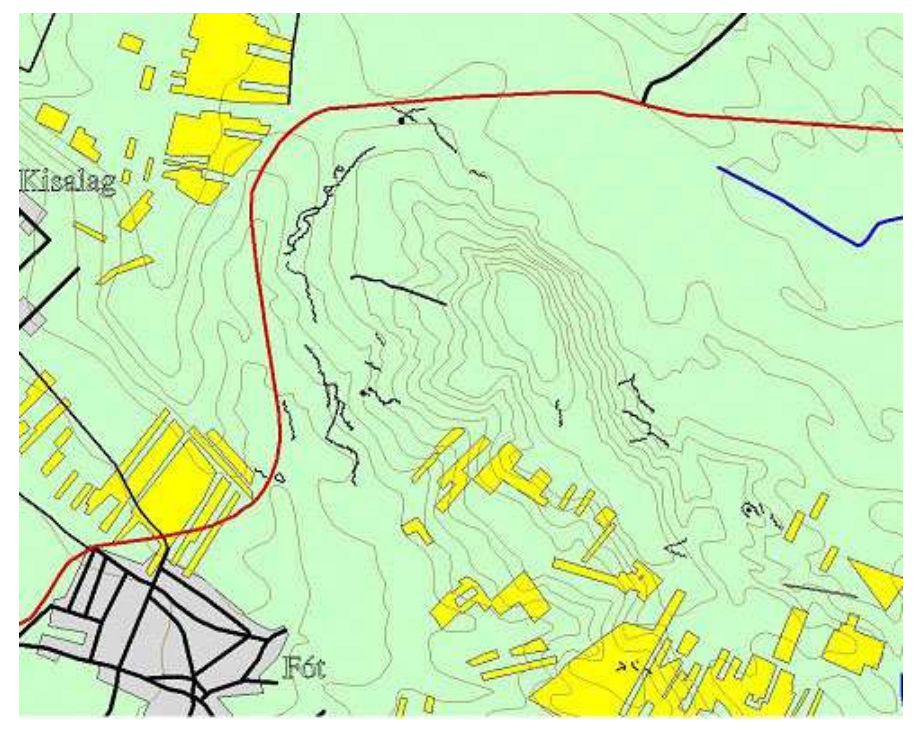

Fig. 10. Trenches and rifle placement near Fót

Tab. 2. The environmental reconstruction features

\begin{tabular}{|c|c|c|c|}
\hline $\begin{array}{l}\text { Feature } \\
\text { Class }\end{array}$ & Feature & $\begin{array}{l}\text { Geometrical } \\
\text { representation }\end{array}$ & $\begin{array}{l}\text { Presentation } \\
\text { Scale }\end{array}$ \\
\hline $\begin{array}{l}\text { Landuse } \\
\text { categories }\end{array}$ & $\begin{array}{l}\text { Country border } \\
\text { Orchard } \\
\text { Wood }\end{array}$ & $\begin{array}{l}\text { Area } \\
\text { Area } \\
\text { Area }\end{array}$ & $\begin{array}{c}\text { always showed } \\
\text { from } M=1: 300000 \\
\text { to } M=1: 300000\end{array}$ \\
\hline $\begin{array}{l}\text { Water } \\
\text { categories }\end{array}$ & $\begin{array}{l}\text { River } \\
\text { Balaton } \\
\text { Marsh } \\
\text { Danube } \\
\text { Danube's island } \\
\text { Stream } \\
\text { Water name }\end{array}$ & $\begin{array}{l}\text { Line } \\
\text { Area } \\
\text { Area } \\
\text { Area } \\
\text { Area } \\
\text { Line } \\
\text { Line }\end{array}$ & Always showed \\
\hline $\begin{array}{l}\text { Traffic } \\
\text { categories }\end{array}$ & $\begin{array}{l}\text { Main road } \\
\text { Road } \\
\text { Crossroads } \\
\text { Dirt road } \\
\text { Railway } \\
\text { Road name }\end{array}$ & $\begin{array}{l}\text { Line } \\
\text { Line } \\
\text { Line } \\
\text { Line } \\
\text { Line } \\
\text { Line }\end{array}$ & From $M=1: 300000$ \\
\hline $\begin{array}{l}\text { Urban } \\
\text { categories }\end{array}$ & $\begin{array}{l}\text { City } \\
\text { Living space } \\
\text { Industrial area } \\
\text { Cemetery } \\
\text { Settlement name }\end{array}$ & $\begin{array}{l}\text { Point } \\
\text { Area } \\
\text { Area } \\
\text { Area } \\
\text { Line }\end{array}$ & To $M=1: 300000$ \\
\hline $\begin{array}{l}\text { Relief } \\
\text { categories }\end{array}$ & $\begin{array}{l}\text { Relief } \\
\text { Height name }\end{array}$ & $\begin{array}{l}\text { Line } \\
\text { Line }\end{array}$ & From $M=1: 300000$ \\
\hline
\end{tabular}

The discolourations of the field above the covered dikes are visible, too. The search for the trenches is a more difficult task. Because of the size and the scale of photos we had to use a loupe. The artillery and the flak placements are bigger than the trenches so the interpretation was easier in this case. Moreover, sometimes these placements are already visible on the maps. We think that we locate almost 100 percent of the anti-tank dikes but only 10-20 percent of the other fortification parts. Beside the map and photo review we discussed with war historians 
and searched for eyewitnesses or any person who participated in building defense line or took part in the fight. We got a lot of interesting information from those individuals. Unfortunately, in some cases we could not verify the information because of access-problems to the different sites mentioned. The figures below represent some typical fortification object scenery, the used data sources, their reliability, and their using prevalence Juhász 2004 [6].

\section{The Reconstruction of Attila-line}

In our example of fortification reconstruction (Attila-line) we deal only with the environmental and object reconstructions. The selected uniform data system was the EOV coordinate system. The GIS database was created with Bentley Microstation and ESRI ArcView software. We carried out the photograph digitization and map transformation on the Microstation. The ArcView used for attribute database creation and the presentation and analysis of the whole data system (Juhász, Mihályi 2003 [7]). The feature classes we created to reconstruct the period environment and the fortification objects can be seen in the Tables 2 and 3. The Figs. 9, 10, 11 represent some scenes from the GIS database.

Our work on the reconstruction of the Attila-line demonstrates that GIS is a very suitable tool for military historical reconstruction. The research we carried out has the following results:

- We can conclude that anti-tank dikes were built only in the Attila I and Attila III lines.
- The Attila II line contained only rifle dikes, rifle and artillery placements.

- It seems that in contradiction to old theories, the Attila II line did not have a horseshoe shape. It was connected to the Attila I line at the area of Maglód settlement.

\section{Conclusions and Further Plans}

We would like to continue our research in several directions. The anti-tank dike system of Attila-line is reconstructed almost completely. The reconstruction of the other fortification objects is still incomplete in the present time. The attribute data collection and process are in progress. The event reconstruction is not a small challenge. We would like to investigate and reconstruct the other Hungarian defence lines, too. So there are quite a few tasks waiting, we hope that we meet the challenge.

\section{References}

1 Detrekői Á, Szabó Gy, Bevezetés a térinformatikába, in Hungarian, Nemzeti Tankönyvkiadó, Budapest, 2002.

2 Kozma E, Héjja I, Stefancsik F, Katonaföldrajzi kézikönyv, in Hungarian, Zrínyi Kiadó, Budapest, 1993.

3 Schmoll E, Haditechnikai alapismeretek. 2, in Hungarian, Selfpublished, Budapest, 1930.

4 Tóth S, Budapest felszabadítása 1944-45, in Hungarian, Zrínyi Kiadó, Budapest, 1975.

5 Ungváry K, Budapest ostroma, Corvina Kiadó, Budapest, 2001.

6 Juhász A, A XIX-XX. Századi tábori eródítések a Kárpát-medencében, in Hungarian, Tinta Könyvkiadó, Budapest, 2004.

7 Juhász A, Mihályi B, Budapest védelmi vonalainak rekonstrukciója, in Hungarian, Geodézia és Kartográfia, Budapest, 1944. 